\title{
RESULTS OF THE EU CROSS-BORDER PROGRAMME ALLOCATIONS AND THEIR GEOGRAPHICAL IMPLICATIONS FOR BORDER REGIONS OF VOJVODINA/SERBIA IN THE 2014-2020 PROGRAMMING PERIOD
}

\author{
Imre Nagy ${ }^{1}$, András Ricz ${ }^{2}$, Renata Fekete ${ }^{1}$ \\ ${ }^{1}$ Department of Geography, Tourism and Hotel Management, University of Novi Sad \\ 21000 Novi Sad, Trg Dositeja Obradovica 3: Serbia \\ nagyi@rkk.hu•reni.fekete29@gmail.com \\ ${ }^{2}$ Regional Scientific Association \\ 24000 Subotica, Matije Korvina 9: Serbia \\ riczandras@rcgroup.co
}

\begin{abstract}
Researching the Autonomous Province of Vojvodina as a region of Serbia and an European Union (EU) border region, we have long been concerned with the raison d'être of cross-border programmes, their impact, sustainability and long-term results. Against that background, the current study is focused on the results of the 2014-2020 cycle. The region of Vojvodina has neighbouring external borders with three EU Member States. While the partner countries have already applied for almost $100 \%$ of the available amounts, the implementation of projects and thus the payment of grants is only $50 \%$ effected so far. Our intention has been to examine the Vojvodina region in terms of cross-border programmes based on already completed projects and running along the lines of different Priorities. The Programme Areas of the four (Hungarian-Serbian, Croatian-Serbian, Romanian-Serbian and Serbia-Bosnia and Hercegovina) Cross-border cooperation programmes do overlap significantly. Primarily, we have been researching the territorial distribution of each, by reference to the locations of project owners and of project activities; as well as the related networking character of the projects implemented in Vojvodina in the Interreg-IPA (Instrument for Pre-accession Assistance) 2014-2020 programming period. It is then in this context that we examine the focal and connection points of the cross-border connections, in this way potentially indicating deficiencies in regard to sustainable project implementation. Without claiming to be exhaustive, we have also sought to reference impeding circumstances relating to a barrier effect that is obviously of particular importance given the fact that external borders of the EU are involved.
\end{abstract}

Keywords: cross-border cooperation, EU external border, Interreg, IPA, Vojvodina/Serbia.

\section{Introduction}

Following the changes of regime in the Central and Eastern European countries (CEECs), and the opening-up of Europe's eastern borders, there has been a raising of the importance of developing border regions and of cooperation with external border regions. Seeking to take advantage 
of economic opportunities, market creation and the free movement of labour and capital, the EU has focused on the development of internal border regions lagging behind and of external border regions, by way of cross-border cooperation $(C B C)$ with them, in this way contributing to knowledge on, and the dissemination of, Community policies in future Member States. The result is for cross-border programmes (the subject of an EU Regional Policy objective) to seek to achieve the support of underdeveloped regions within the EU, by way of cooperation among peripheral bordering regions. Later (following the accessions of 2004-2013), CBC programmes also became an instrument of enlargement policy in terms of the promotion of EU integration (Ocokoljic, 2013; Medeiros, 2018).

$\mathrm{CBC}$ can be defined as cooperation of an institutionalised nature between regional and local authorities in the border area of neighbouring countries. Cooperation within the EU and at the Union's external borders thus aims to address issues extending beyond the borders of individual communities, with these including attempts at the exploitation of border situations, with borders serving economic and cultural exchange, and with regional links being built with a view to the achievement at regional level of development goals relating to the promotion of economic development, social affairs, the rights of minorities, cross-border employment, the boosting of trade relations, environmental problems, and so on (Perkmann, 2003; Popescu, 2008; Scott, 2015; Nagy, 2020). None of these goals of development are achievable where CBC processes are not effective (Medeiros, 2018). In this connection, Tamminen (2012) explains that the level of cooperation arising in border regions should no longer be controlled by the state(s), but rather involve local actors - at their initiation, with effects being seen, not as classic external relations, but rather as 'neighbourly relations'.

In addition to the Interreg programme for cooperation between border regions within the EU, and the ENP ${ }^{1}$ CBC programs for cooperation on external borders (which cover regions on both sides of the EU's eastern borders, and has a single budget, common governance structures, and a common legal framework and implementing rules, the EU has also extended cooperation to the countries of the Western Balkans, with the CBC between them and the EU taking place via funding under the Instrument for Pre-accession Assistance (IPA) (Bastian, 2011, March 11; Demidov \& Svensson, 2011).

In-depth research into co-operation at the EU's eastern (external) borders has been conducted in respect of the Russian-EU and Polish-Belarusian-Ukrainian border regions in particular. Such studies allow it be concluded that the CBC of Russia's north-western and western border regions (in relation with Finland and Estonia) involves municipalities, NGOs and business institutions, facilitated by agreements on the easier crossing of local borders, even as production facilities located in Karelia contribute to technology transfer in the EU (Kolossov, Klemeshev, Zotova \& Sebentsov, 2015).

In the Polish-Ukrainian-Belarusian border region, cooperation is based on the Ukrainian and Belarusian minorities living in Poland, as well as the Polish minority living in the neighbouring countries, and this is defined by mutual knowledge of languages, family relations, natural values, common cultural and monumental values originating in the historical past, and relations pertaining between scientific institutions. The participation of Belarus in CBC relations is limited by political circumstances and the centralised nature of the administration (Dołbłasz, 2018).

\footnotetext{
${ }^{1}$ European Neighbourhood Instrument - this instrument supports the Eastern Partnership between the EU and its eastern neighbours, the Partnership for Democracy and Shared Prosperity and the Union for the Mediterranean in the southern neighbourhood, the implementation of regional cooperation throughout the European Neighbourhood, inter alia in the framework of the Northern Dimension policy or the Black Sea Synergy, as well as, primarily in the case of CBC, the external aspects of relevant macro-regional strategies (EC, 2014).
} 
Following the changes of regime in the CEECs, as well as the 2004-2013 EU accessions, there have been some modifications to the CBC engaged in by border regions in the states of the Western Balkans, since it is those that are reached by the EU's external border. The transition to a market economy began in Serbia approximately 10 years later, and decentralisation processes started then, as did contacts and cooperation with the EU. With the enlargement, Serbia was 'repositioned' at the EU's external border, as a result of which (thanks to the EU's neighbourhood policy, first the CARDS ${ }^{2}$-Interreg and then the IPA I and II funding became available, to implement the objectives of pre-accession processes. Until 2014, as a pre-accession country, Serbia could only apply for IPA components 1 and 2, which supported institution-building and cross-border activities. Approximately $10 \%$ of the budget allocated to Serbia could be used for the CBC, which supported the building of relations with Hungary, Romania, Croatia, Bosnia and Herzegovina, Bulgaria, Montenegro, and, from 2014, Northern Macedonia; as well as the development of laggardly border regions.

The Autonomous Province of Vojvodina represents an EU NUTS 2 region located in the northern part of Serbia, with a population of close to 2 million people and an area of $21,614 \mathrm{~km}^{2}$. The territory of Vojvodina became part of the newly formed Kingdom of Serbia-Croatia-Slovenia in 1920, after World War I. Even after World War II, Vojvodina remained part of the Second Yugoslavia (SFRJ) ${ }^{3}$, as an autonomous province of Serbia, and then, following the break-up of Yugoslavia, as the northernmost province of the independent Republic of Serbia. The province is bordered by three EU Member States: Hungary and Croatia along the entire Serbian border, and Romania on two thirds of its border with Serbia; as well as by Bosnia and Herzegovina on a small section of the national border. As a result of historical circumstances and the disintegration of the Second Yugoslavia, former trade, economic and civil relations were severed in the early 1990s, only to be revived in the context of Serbia's EU integration processes in the mid-2000s. Beside the Serbian population, the ethnic structure among people living in the province includes Hungarians, Slovaks, Romanians, Ruthenians, Croats etc. Where cross-border relations are concerned, this represents a factor both facilitating and necessitating the pursuit and maintenance of cooperative relations, even as relations between the individual nations and their mother nation are also maintained and developed.

\section{Experience to date with cross-border relations (2004-2006, 2007-2013)}

An examination of the structure of cross-border programmes implemented in the 2004-2006 planning period (as well as their objectives and project results) allows it to be stated that Vojvodina still needs to allocate significant resources if there are to be any tangible results of cross-border programmes for the general population. It is by no means questionable that the approximately EUR 10 million of development funding received under the above-mentioned programme has been allocated to the right places, but this has proved effective at the local level, for a local community or at best a municipality/city. The effect on overall regional development has remained minor.

Most projects mainly offer opportunities for development to rural society - understandable enough given the demographic characteristics of Vojvodina. An analysis of the activities encom-

\footnotetext{
${ }^{2}$ Community Assistance for Reconstruction, Development and Stabilisation (CARDS) for the Western Balkan countries

${ }^{3}$ The Socialist Federal Republic of Yugoslavia
} 
passed by winning projects reveals the need for human resources to be developed. Leaving aside the hard-infrastructure projects, almost all the types of projects have so far involved some form of training - for which there has been broad demand during the implementation to date, bearing in mind the excellent opportunity afforded for stakeholders to learn the basic skills essential for both EU accession and the allocation of additional resources.

The projects implemented put cooperation in place and helped establish opportunities within local communities capable of being used to achieve economic development even where other EU support is lacking. In many cases, the goal has been to strengthen sole proprietorships by exploiting the potentials of a partner country. If individuals become stronger, the community itself will become stronger, and will be in a position to generate further improvements. The importance of the programmes to date thus lies in the way that a path individual subjects need to take in order to develop is indicated (Ricz, 2013).

As regards the programmes implemented between 2007 and 2013, the largest cities in Vojvodina - Novi Sad and Subotica - as well as some other large and medium-sized towns were in a position to absorb most of the payments, in both relative and absolute terms, with most projects given effect to being in these areas. As the main aim of the programmes examined was to reinforce cross-border impacts and to reduce the backwardness of peripheral areas, regions physically closer to the border were able to allocate a higher proportion of funding, with effects therefore proving more significant in a manner tangible in terms of indicators of both an infrastructure-related and social nature.

The several border municipalities participating in project implementation included Kanjiža, Novi Kneževac, Subotica, Sombor, Kikinda and Vršac, with significant resources therefore being allocated. However, a comparison of development indicators characterising these municipalities recently and under pre-project conditions is not able to point to any outstanding development having taken place, with this denoting a clear rejection of the assumption that the mobilisation of EU funds offers the key moment of Vojvodina's development. The development trajectory of the larger cities seems to break in 2012, while smaller ones show slight development growth.

Significant development cannot therefore be said to have been generated by the resources present under cross-border programmes, though in the case of smaller settlements these resources offered development alternatives exploited by the municipalities already referred to, with effects attested to by measurable data (Ricz, 2018). Even then, there are many cases typifying the implementation of other cross-border programmes (to which the international literature also draws attention), whereby projects have no spill-over or sustainable effects, generating no additional activities after financial closure, and thus having no continuation (Knippschild, 2005). Such analysis of project sustainability and spill-over effects by the authors made use of a scoring method referring to projects under the 2007-2013 Programming Period (Nagy, Ricz, Ribár \& Nagy, 2015).

While projects implemented under the $\mathrm{CBC}$ programmes indeed failed to yield significant change in economic and financial terms, they did impact on applicant organisations availing of the opportunity to learn about EU programmes. Successful project implementation pointed to the communities characterised by sustainability, as well as to the nature of sound project ideas capable of being developed further. The results thus exemplify the benefits of EU funding for community development (Nagy, 2020).

Under the work detailed here, our aim has been to present the results achieved in border areas of Vojvodina as regards regional development by way of projects financed under First Calls of the 2014-2020 IPA CBC Programme. Among the Programme's individual projects, those examined related to elements of economic, tourism-related and infrastructural development, given the ways 
these might be expected to exert a significant impact on the aforesaid regional development. We wanted to present main results, and to draw a parallel with the previous budgeting period, in which EU funds were proved to have had little impact on territorial development in Vojvodina. Our work is only the first step in a comprehensive analysis of the entire programme, the final evaluation of which will be able to draw deeper and more in-depth conclusions only after completing the programme cycle, by using appropriate indicators (e.g. Territorial Impact Assessment Tools in Cross-Border Cooperation).

\section{Methodology of the study}

Although it would be more realistic and plastic to present the participation intensity of Vojvodina municipalities by taking account of the amounts of support implemented in projects (grant tranches), in this study we based our analysis on the number of projects (see Fig. 1-4), given the way in which descriptions of projects and reports on results fail to reveal the distribution of subsidies by project partners.

Cross-border relations are presented and depicted in line with the nature of the cooperation engaged in by participating municipalities (in economic development, tourism, culture, the environment, etc.), as opposed to by reference to the priority grouping of each IPA CBC Programme, given that each example of the latter has a different denomination system by which to categorise cooperation priorities, necessitating the establishment of intervention groups with the effectiveness of each shown plastically.

These maps of $C B C$ relations along sections of the border also refer to types of cooperation and the way they are delimited, in line with whether or not this is cooperation related directly to the borderline (Type 1), other cooperation involving intra-regional areas (Type 2), cooperation between regional centres (Type 3), or some unusual form (Type 4) (Nagy, 2020). ${ }^{4}$

The diversity of relations of a settlement can be viewed in terms of the number of project cooperations of a settlement with another settlement or settlements. Where the number of project co-operations of two settlements is equal, the one that implements its partner project relations with as many settlements as possible is the most diverse.

Regarding the relations by type of settlement, the variability factor is also to be found as we examine the relations between the different types of settlement (village, town, city or county seat, regional centre), with an influence also potentially exerted by relations among institutions participating in the cooperation.

Where those institutional relations are concerned, the study sought to analyse homogeneity of competence, and the proportion of $\mathrm{CBC}$ relations of institutions of the same level and nature in the breakdown of each border programme, where this is considered to offer conclusions as to how realistic non-competent relations are, and as to the effects of lack of competence in the assessment of project implementation.

Assessment of obstacles as regards reducing the barrier effect and territorial resources (endowments) should have been commenced with within the framework of the Territorial Impact Assessment right from the 2014-2020 programming period (Medeiros, 2015). In our opinion, the need to assess the cross-border impact advocated during project planning relates closely to any

\footnotetext{
4 The borderline-related (symmetrical neighbourhood) co-operation territorial type, the territorial type of the border region not related directly to the borderline, the $\mathrm{CBC}$ type of regional centres, the irregular $\mathrm{CBC}$ type.
} 
reducing of the barrier effect. This is to say that, if a project cannot achieve a real $\mathrm{CBC}$ effect, then the reduction of barrier effects cannot be fully achieved either, though there may be many other reasons for that. In the present study, we point to conditions whereby the barrier effect may be reduced, with those based on the experience so far, and following the summative factors by Medeiros (2018).

\section{The EU's CBC-funding frameworks in Serbia, 2014-2020}

\section{CBC funding frameworks in Serbia}

The EU funding available to Serbia has been disbursed from IPA funds via IPA-Interreg Programmes. Through until 2014, Serbia only made use of Components 1 and 2 of the IPA Programme, while Component 3, the so-called IPARD, was phased in from 2018 - its goal being the support of agriculture, and its status being that of first programme financed from the EU budget with a targeting at profit-oriented entities. In the present study, we seek to focus on CBC alone, though we do refer to the weight of the $\mathrm{CBC}$ framework in the overall EU framework for Serbia, while also presenting the structure of the framework for Serbia as a whole (Table 1).

Table 1. Value of the $\mathrm{CBC}$ programmes allocated to Serbia - as part of the overall programme run by the EU (EUR)

\begin{tabular}{|c|c|c|c|c|c|c|}
\hline $\begin{array}{c}\text { Programming } \\
\text { period }\end{array}$ & SERBIA IPA CBC & HU-RO-SER & HU-SER & CRO-SER & RO-SER & SER-BiH \\
\hline $2004-2006$ & 31923029 & 31923029 & - & - & - & - \\
\hline $2007-2013$ & 71728241 & - & 33969179 & 5400000 & 19559062 & 12800000 \\
\hline $2014-2020$ & 188323436 & - & 65124000 & 34293188 & 74906248 & 14000000 \\
\hline
\end{tabular}

Source: authors' elaboration on the basis of HUROSCG (2009), INTCROSER (2014), IPSERBIH (2014), INTROSER (2018) and INTHUSER (2020).

During the period under review, Serbia participated in EU-funded cross-border development programmes involving all of its neighbours (except Kosovo, with which bilateral relations are not settled). With regard to Vojvodina, four CBC programmes are relevant: in the case of Hungary and Croatia, the entire programme area is implemented in Vojvodina, so this is of key importance. In the case of Romania there is not full implementation within the province, but the budget of this programme is much larger than that of the other two, with the result that the significance can be seen as greater. In the programme to be implemented with Bosnia and Herzegovina, Vojvodina has the opportunity to cooperate only on the basis of Srem county, hence a level or programme significance much lower than with the previous three. It can be seen from the list below that, thanks to there being four programmes, at least two are available in each of the province's municipalities, with the effect that virtually the entire population here has the same access to these EU programmes.

The specificity of the projects is such that partners in the two given countries apply as applicants of equal status when it comes to implementation, the consequence being for both the activities and the related budget to be divided approximately equally between the two countries. The principle of the whole programme is based on joint planning, implementation, budgeting and management, for the observance of which similar competencies of the partners are inevitable. 
Vojvodina participates in joint programmes involving all the countries neighbouring Serbia. The Hungarian-Serbian programme will be announced in the fourth budgeting period, while the other two will be announced in the second. The programmes extend to the entire territory of the Vojvodina and, if we analyse them territorially, we find that there are no municipalities of the province that do not participate in at least two of the four Programmes. The most extensive example is the Hungarian-Serbian Programme, covering the entire province, while the Croatian-Serbian Programme covers its western part only, even as the Romanian-Serbian programme is confined to the eastern part. The Serbian-Bosnian programme involves only a southern district of the province (Table 2).

Programmes' main priorities have been developed in line with similar principles. The main themes are the environment, economic development, the development of cross-border infrastructure, social inclusion and health development, water management, the conservation of natural and cultural heritage and improved people-to-people relations.

Table 2. A brief comparative analysis of the Interreg-IPA CBC Programme Areas (2014-2020)

\begin{tabular}{|c|c|l|}
\hline $\begin{array}{c}\text { IPA Programme } \\
\text { areas }\end{array}$ & $\begin{array}{c}\text { Budget } \\
\text { (EUR) }\end{array}$ & \multicolumn{1}{c|}{ Counties / Districts } \\
\hline Hungary-Serbia & $76,616,000$ & $\begin{array}{l}\text { Csongrád and Bács-Kiskun counties in Hungary, } \\
\text { Districts of West Bačka, North Bačka, South Bačka, North Banat, Central } \\
\text { Banat, South Banat and Srem in Serbia. }\end{array}$ \\
\hline Croatia-Serbia & $40,345,000$ & $\begin{array}{l}\text { Croatian side: counties of Osijek-Baranja, Vukovar-Srijem, Brod-Posavina } \\
\text { and Požega-Slavonia, } \\
\text { Serbian side: Districts of North Bačka, West Bačka, South Bačka and Srem } \\
\text { (all in Vojvodina) and Mačva District. }\end{array}$ \\
\hline Romania-Serbia & $88,125,000$ & $\begin{array}{l}\text { Romanian side: Timiş, Caraş-Severin and Mehedinţi Counties, } \\
\text { Serbian side: North Banat, Central Banat, South Banat Districts (in } \\
\text { Voivodina) and Braničevski, Borski and Podunavski Districts. }\end{array}$ \\
\hline $\begin{array}{c}\text { Serbia-Bosnia- } \\
\text { Hercegovina }\end{array}$ & $16,223,529$ & $\begin{array}{l}\text { Serbian side: a smaller part of the Autonomous Province of Vojvodina - } \\
\text { Srem District., } \\
\text { Bosnia and Herzegovina: the municipalities bordering with Vojvodina are } \\
\text { from Brčko District, and Bijeljina Region. }\end{array}$ \\
\hline
\end{tabular}

Source: based on INTCROSER (2014), IPSERBIH (2014), INTROSER (2018) and INTHUSER (2020).

Based on the project priorities listed above, the Joint Secretariats have launched calls for proposals for project funding, typically for non-profit organisations, mainly state and civilian institutions; both strategic and open calls for proposals have been launched, except in the cases of the Croatian and Bosnian programmes. Strategic projects are typically larger investments supported in consensus by the governments of two countries, with some large-scale infrastructure investment included in each case. The open calls are intended to support smaller-volume activities of the organisations identified in a call, whose activities are in line with the priorities of the given Programme. In the study sample, only the strategic and the first open calls for proposals (including the second call in the Croatian-Serbian Programme) were taken account of. On the basis of these, a total of 137 projects were funded in Vojvodina:

- in the Hungarian-Serbian relationship: 71 projects,

- in the Romanian-Serbian relationship: 21 projects,

- in the Croatian-Serbian relationship: 39 projects,

- in the Serbian-Bosnian relationship: 6 projects. 
Out of all the projects, 7 were strategic -5 in the Hungarian and $2-$ in the Romanian Programmes, while the remaining supported projects were selected through open calls. Regarding project management within the CBC framework, Serbia (Vojvodina) accounts for $42 \%$ of the leading partners in the HU-SER CBC Programme, $48 \%$ in the CRO-SER Programme and $33.3 \%$ in the RO-SER Programme.

In our view, the explanation for such a structure close to a proportional distribution lies in long-term cross-border relations pertaining in the HU-SER and CRO-SER context. Under the HU-SER Programme, this is the fourth edition, denoting good relations established over recent decades between the institutions present and operating on either side of the border, with both parties possessing adequate capacities where project implementation is concerned. That said, we may not neglect the 'Hungarian-Hungarian' relations pertaining between Hungary and the Hungarians of Vojvodina, which give a special impetus to the cross-border programmes. With regard to the CRO-SER Programme, a relationship close to parity is also ensured by good relations based on a common language (Serbian) and a very similar language (Croat), as well as the previous many years of coexistence, in addition to the adequacy of both sides. The proportion of leading partners in the RO-SER Programme has shifted slightly in the direction of Romania, which is due to the fact that, along this border section, none of the clauses characterising the previous two programmes were given. The Romanian-Serbian border is a strong linguistic border, which also had limited passage for a long time, ensuring little contact between the inhabitants of the two countries. The fact is therefore that strong Romanian institutions (universities, hospitals, etc.) operate in a region with Timisoara as its regional centre, even as things are less pronounced on the Serbian side, with the balance thus tilted in the direction of leading partners from Romania.

\section{Peculiarities of the CBC spatial relations applying to Vojvodina}

We have examined Serbia's CBC with the neighbouring EU Member States through the Autonomous Province of Vojvodina as an EU NUTS 2 region; as well as its cross-border relations. In this way, the neighbouring EU Member States are covered, but so is Bosnia and Herzegovina as a neighbouring country affected by the Interreg-IPA 2014-2020 Programme.

In the examined period, 137 Interreg-IPA CBC projects were implement. At the level of settlements, this relates to 52 located in the border regions of the neighbouring countries that have set in train CBC involving 53 settlements in Vojvodina (Table 3.).

Table 3. Settlements participating in Programmes under Interreg-IPA CBC 2014-2020, with respect to the cross-border cooperation engaged in by Vojvodina

\begin{tabular}{|l|c|c|c|c|c|c|}
\hline Territorial level & SER/VOJV & HU & CRO & RO & BiH & Total \\
\hline Villages & 39 & 14 & 11 & 6 & - & 70 \\
\hline Towns & 12 & 6 & 2 & 1 & 1 & 22 \\
\hline Regional centres & 2 & 3 & 4 & 2 & 1 & 11 \\
\hline Total & 53 & 23 & 17 & 9 & 3 & 105 \\
\hline
\end{tabular}

Source: developed by the authors on the basis of HUROSCG (2009), INTCROSER (2014), IPSERBIH (2014), INTROSER (2018) and INTHUSER (2020). 
Thus far into the programming period, the distribution of implemented projects by settlement is disproportionate, with a prevalence of relationships concerning regional centres, city pairs and city+other settlement. Where the seats of project partners from Vojvodina are concerned, regional centres of power emerge as well-outlined, given their significant territorial participation. Examples here would be large cities like Novi Sad, Subotica, Sombor, Kikinda and Sremska Mitrovica, as well as certain towns like Kanjiža and Novi Bečej. When it comes to the Hungarian-Serbian Programme, there is seen to be a group of projects cooperating mainly on ethnic grounds, concentrated in the northern part of the province. The same kind of situation applies along the eastern border in the Romanian Programme, just as the Subotica-Sombor axis is significant in the Croatian programme.

An examination of different aspects to project structuring allows for the outlining of four well-defined groups of topics, covering almost the entire territory of Vojvodina. These thematic groups relate to the development of infrastructure (including public roads and cycle paths), as well as transport by rail and water, as typically aimed at the accessing of border crossing-points. In addition, some projects relating to the environment, water management, culture, health, tourism and economic development have also involved larger-scale developments relating to infrastructure. Without exception, the strategic projects entail infrastructure being constructed, with examples including the planned renovation of the Szeged-Subotica railway line, the construction of a road to the Rabe-Kübekháza border crossing, the navigability of the Bega Canal, the equipping of the hospital in Vršac with medical instruments, the construction of the wastewater treatment plant in Kanjiža and the development of the Tisa flood protection system.

Economic and tourism-related development accounts for approximately half of all projects $(47.4 \%)$, as the eligible priorities of all four programme areas included these issues. With regard to tourism, supported new developments are mainly based around built and natural heritage $(24.8 \%)$. In turn, the economic projects see support extended for the development of the labour market, the enhancement of labour mobility and the promotion of social enterprises. The share of economic development projects should anyway be emphasised as a good indicator of the significance assigned to economic development in peripheral areas as programmes were being planned for. Together with infrastructure projects, economic development is the intervention sector exerting the greatest impact on regional development. While the examination of previous programmes fails to show $C B C$ Programmes having a significant impact on the territorial development of Vojvodina, the share of programmes relating to economic development was not as high at that time (Ricz, 2018).

For as long as there is continued non-completion of the whole list of funded projects under all four Programme Areas (such that results will not be examined and summarised on the basis of project outputs), we cannot compare the extent to which territorial development has been boosted by cross-border projects. While appropriate methodology is in place for such study, we see no point in a partial examination.

While the development of relations between people and different communities was primarily supported under the Hungarian-Serbian Programme (where it appears as a separate sub-priority), the matter is present, if to a more limited degree, in all programme areas. This extends to almost any small-scale project that somehow appears in the field of relationships between people on the two sides of a border, be it in the field of culture, sport or education. What are mainly involved here are soft projects contributing to the financing of certain series of events, training courses or cooperation programmes between young people and children. The other category includes all projects that do not appear in any of the previous groups, but among them it is environmental protection and the field of health that are expressed most, given the need for significant progress in terms of development. 
The examination of the implementation of certain projects in line with the distribution of different border regions yields findings as follows.Where the settlements of Vojvodina are concerned, the Hungarian-Serbian Programme is most significant, with several small settlements at the border (Tavankut, Svetozar Miletić, Totovo Selo, as well as Algyő, Ásotthalom, Üllés, etc. on the Hungarian side) involved in some projects. However, it is the projects involving institutions from Szeged, Novi Sad and Subotica that prove predominant, including more than half of all project partners, and thus showing clearly how most $\mathrm{CBC}$ relations take place in this area. This can be explained in part by the territorial distribution of 'Hungarian-Hungarian' relations, as the block area of the Hungarian national minority living in the territory of Vojvodina is more or less also located within the Bajmok-Temerin-Horgoš triangle (Fig. 1).

The Croatian-Serbian Programme seems overly focused on regional centres, as dominated by the Novi Sad-Osijek relation, with project groups from Subotica, Sombor and Vukovar at best sporadic, even as relations between small settlements are seen to be negligible. The relations between small settlements do not in fact characterise relations between neighbouring places, the organisation rather being on an ethnic basis - within the framework of which the Serbian population and settlements of the Croatian side maintain good relations with the settlements of Vojvodina (Fig. 2).

The Romanian-Serbian Programme mainly brings in the larger towns and regional centres from Banat (Kikinda, Pančevo, Vršac, Bela Crkva) as project implementation venues, though Totovo Selo, Senta and Kanjiža are also involved as less important ones that serev to reduce the concentration on regional centres and towns. In this border region as regards Romania, the attractiveness of Timisoara and, to a lesser extent, Resita prove less well-defined on the basis of the co-operation associated with them (Fig. 3).

In the Serbian-Bosnian Programme Area there is a completely unusual predominance of projects that do not belong to this eligibility area, like Novi Sad, and Sarajevo - this partly being due to the extremely large programme area on the Bosnian side (Fig. 4). Thus means that, despite belonging to the official programme area, certain places may be very far from Srem District itself, the latter being the only representative of Vojvodina in the Serbia-Bosnia and Herzegovina IPA CBC programme, and partly connected with the seat of the project beneficiaries, as in several cases, located outside the programme area, even if the activities as such are primarily carried out within it.

All programme areas are characterised by project dumping that reflects the relations pertaining the regional centres, and that in many cases actually fails to further Programmes' basic objectives, i.e. cooperation involving areas directly adjacent to borders, the development of peripheries and the development of people-to-people border contacts. This is particularly noticeable in the lack or paucity of connections between the settlements separated by administrative borders.

With regard to the types of $C B C$, the relationship type of regional centres (Type 3 ) is dominant in all border programmes, as is partly explicable by reference to the professional, financial and external relationship capital of county- and regional-level institutions. Also includeded are connections of sub-regional and regional centres, which have a direct cross-border connection as well, in many cases (Szeged/HU-Subotica/SER or Kikinda/SER-Timisoara/RO). It is likewise frequent for project implementation to take place in a border region, even as the seat of the implementer of the application (if a state or regional organisation) is located far from the border. In this case, a question arises as to whether there is sufficient competence, professional preparedness and field knowledge within the framework of a physically distant institution, to provide an answer to a problem along the borderline. This phenomenon is not unique in the region, being also widespread in other border areas. More in-depth study is recommended if long-term results are to be revealed. 

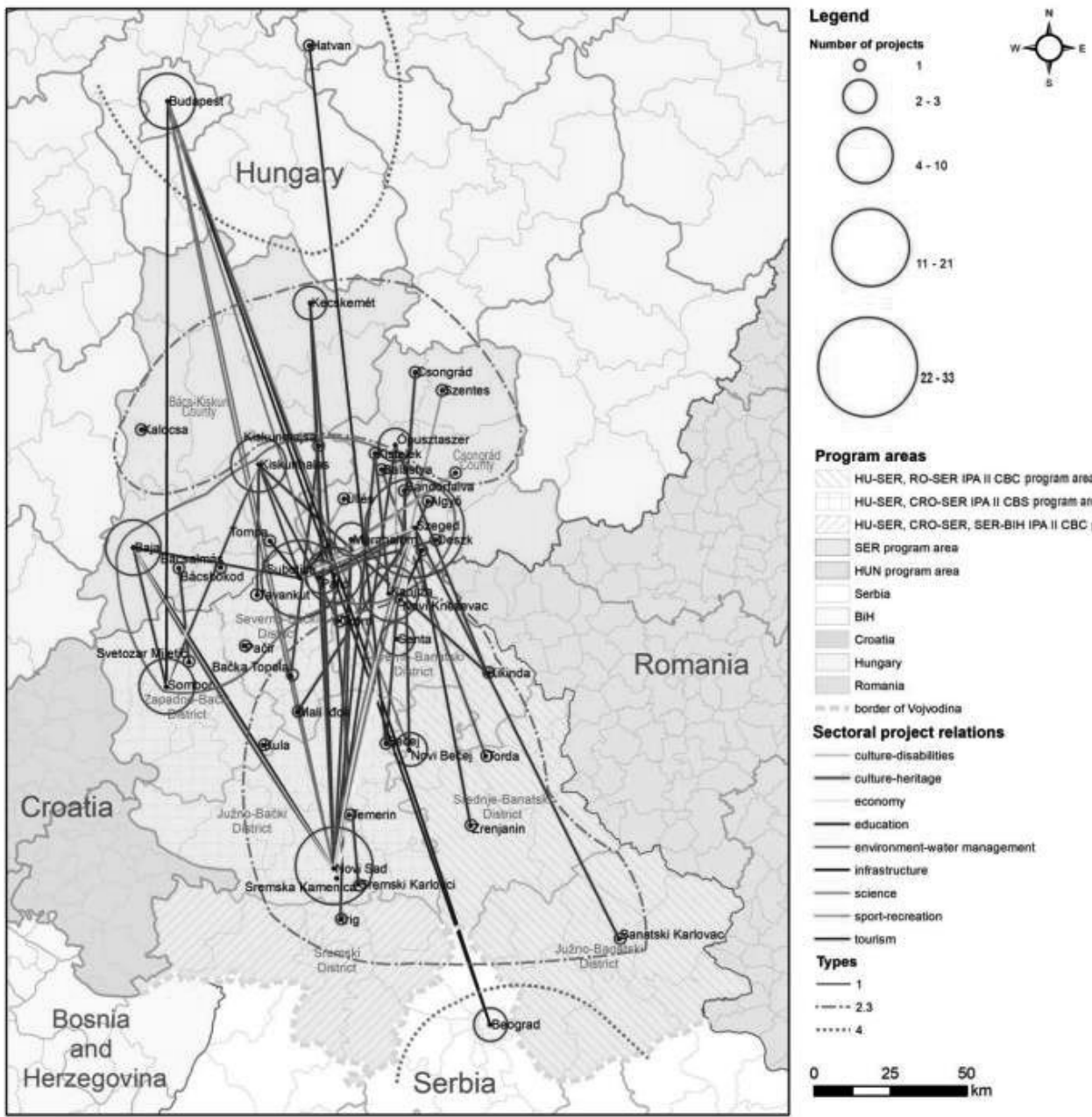

$$
\begin{aligned}
& \text { HU-SER, RO-SER IPA II CBC program aress } \\
& \text { HU-SER, CRO-SER IPA II CBS program anoas } \\
& \text { HU-SER, CRO-SER, SER-BIH IPA II CBC pr. } \\
& \text { SER program area } \\
& \text { HUN program area } \\
& \text { Serbia } \\
& \text { BiH } \\
& \text { Croatia } \\
& \text { Hungary } \\
& \text { Ramania } \\
& \hline
\end{aligned}
$$

Sectoral project relations

culture-disabatities

- culture-heritage

economy

- education

- environment-water management

- infrastructure

- science

sport-recreation

- tourism

Types

Types
$-\cdots 23$

$\ldots . .4$

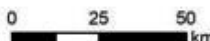

Figure 1. Intensity of spatial connections characterising Hungary-Serbia IPA CBC project applications as arranged in terms of the type of cooperation

Source: elaborated by the authors on the basis of EU data.

The number of borderline-related settlements (involving the symmetrical neighbourhood co-operation territorial type) is still negligible, and if these settlements do participate, the partner is not from the immediate neighbouring settlements, but is an institution from a more distant settlement. Only in multi-partner projects are there examples of a neighbouring settlement also being involved. Such projects are mostly of the people-to-people type. Information gathered in this field shows how, in most cases, existing good relations are being developed further between institutions and people living on both sides of a border, implementing CBC projects mainly in the fields of culture and sport, with tourism only present to a lesser extent. 


\section{Legend}

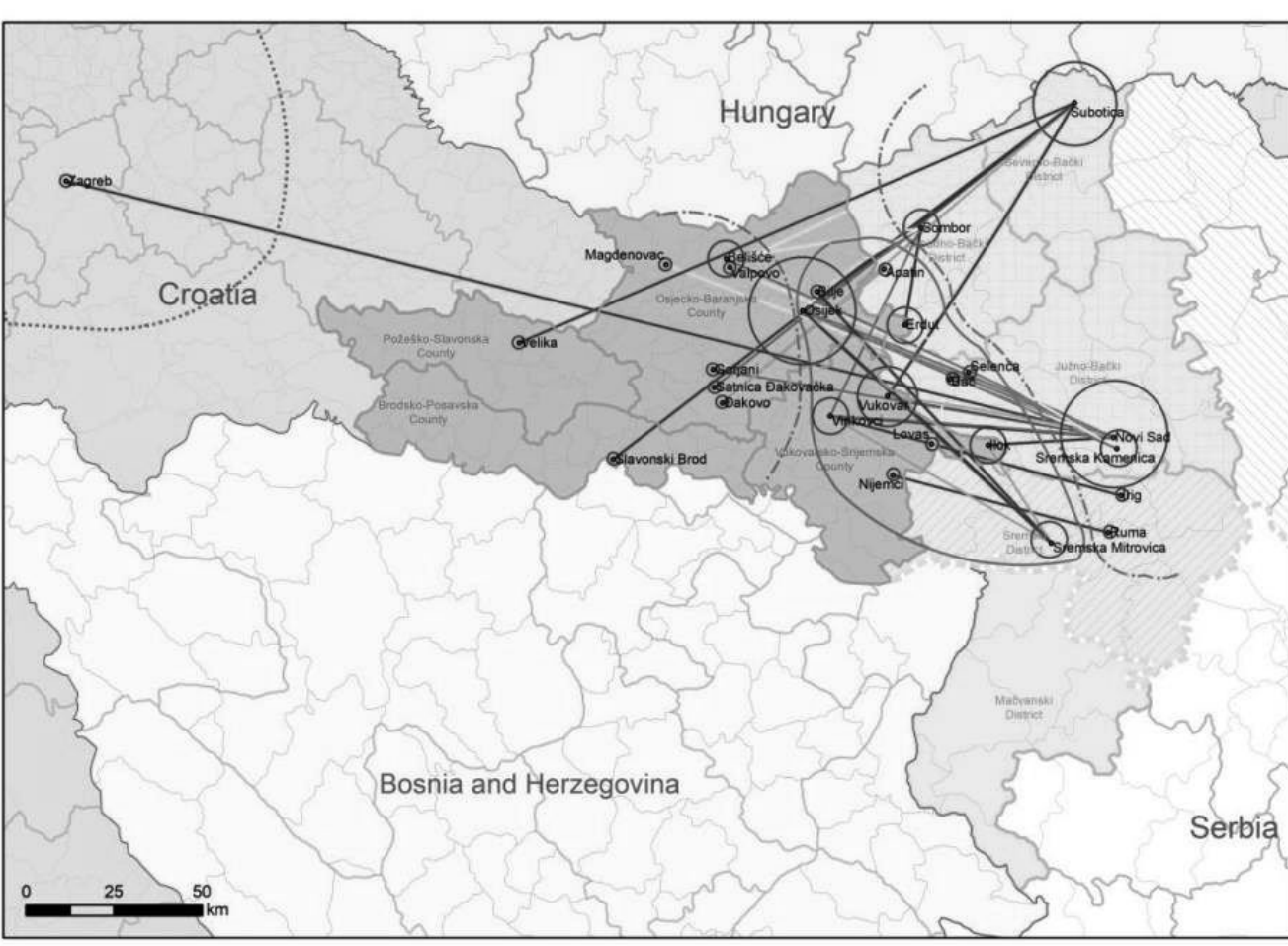

Number of projects

$\bigcirc^{\circ} \quad 1$

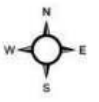

(2.5
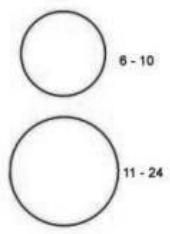

Program areas

HU-SER, RO-SER IPAII CBC propram areas HU-SER, CRO-SER IPAII CBS program areas HU.SER, CRO-SER, SER-BIH IPAIII CBC PF.

BiH

Serbia

croatia

Hungary

Romania

$\square$ CRO program area

-- border of Vojvodina

\section{Sectoral project relations}

economy

- environment-water management

- tourism

Types

$-\cdots 2.3$

Figure 2. Intensity of spatial connections between Croatia-Serbia IPA CBC project applications as arranged in terms of the type of cooperation Source: elaborated by the authors on the basis of based on EU data 


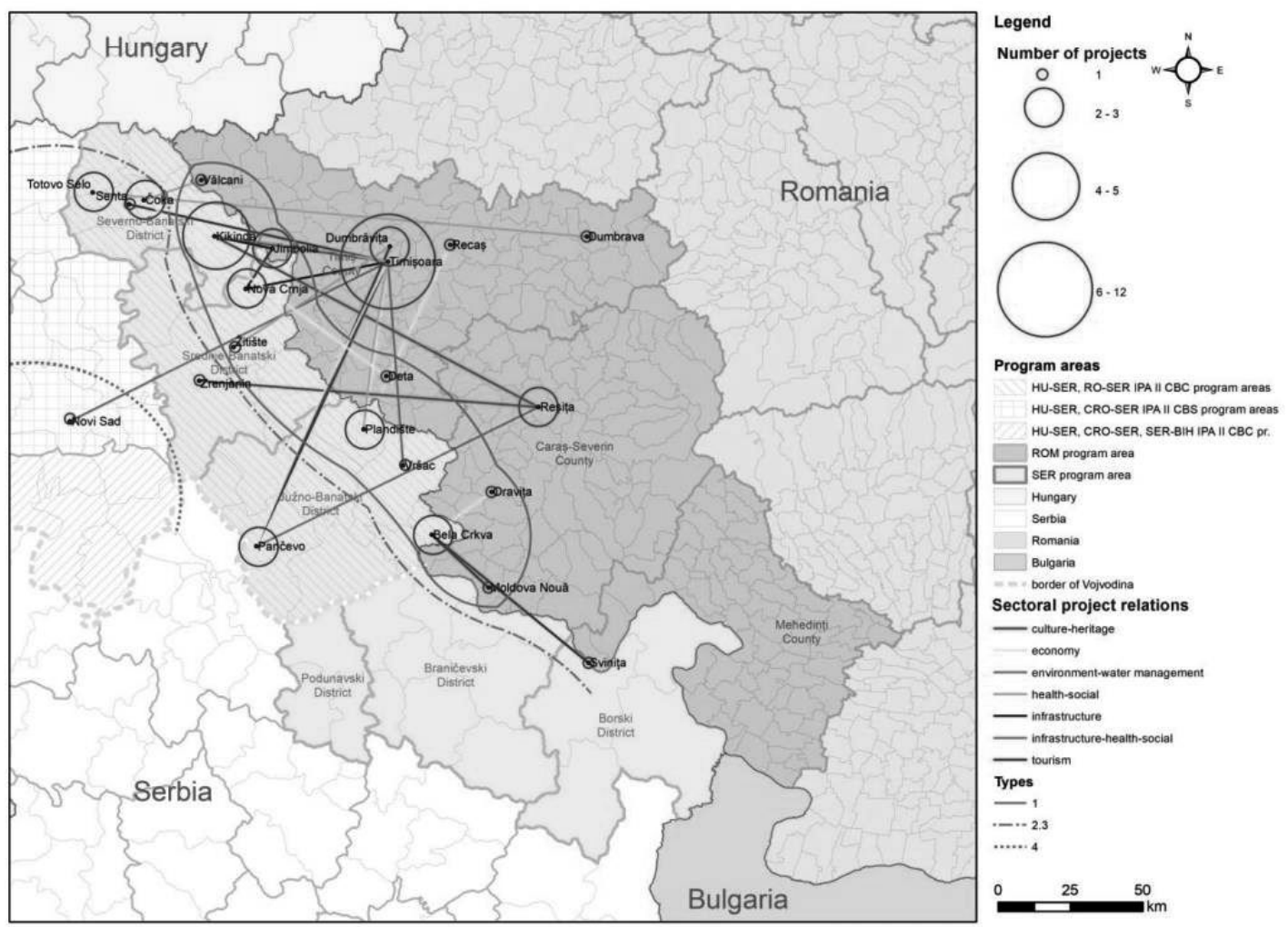

Figure 3. Intensity of spatial connections between Romania-Serbia IPA CBC project applications as arranged in terms of the type of cooperation Source: elaborated by the authors on the basis of EU data. 


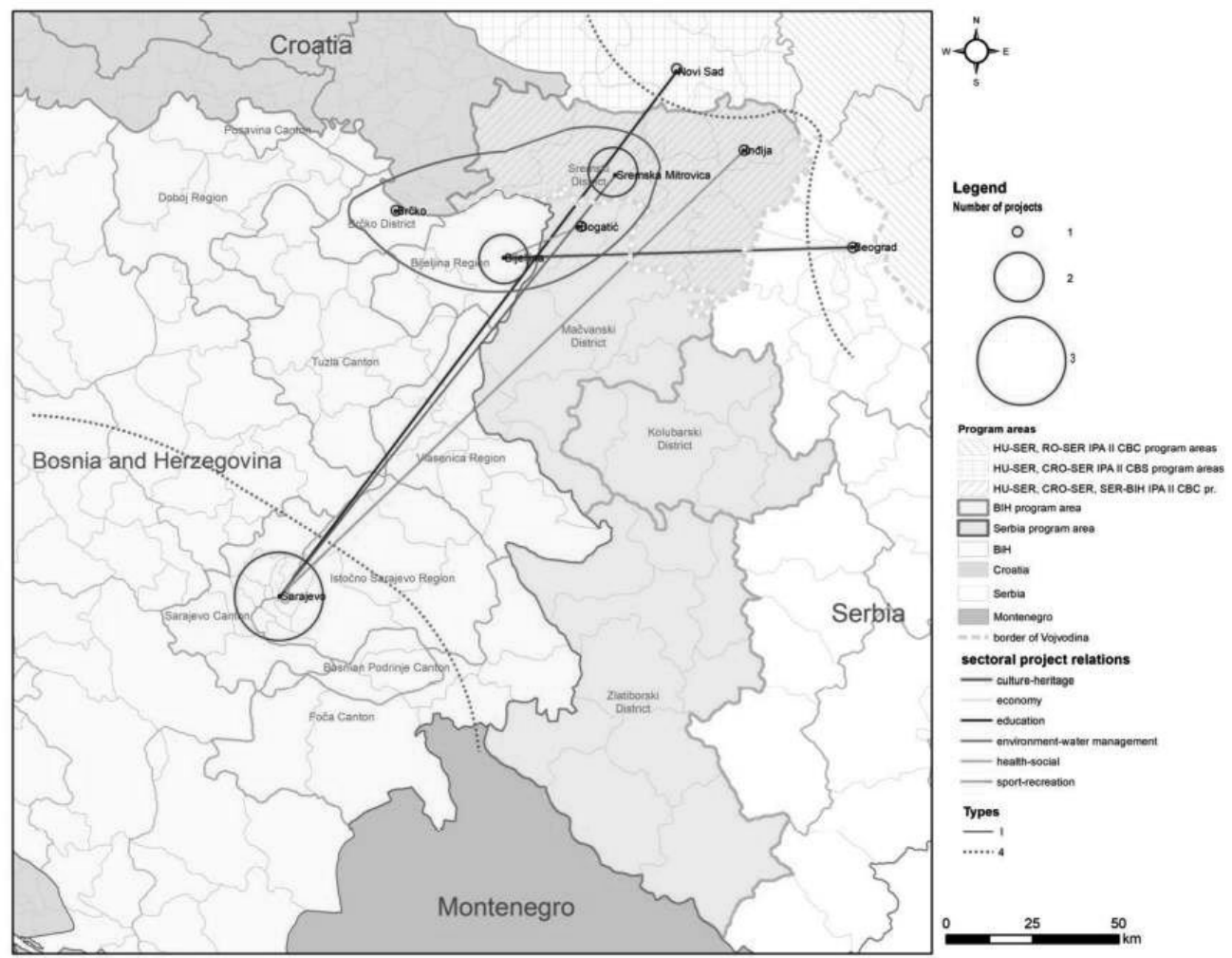

Figure 4. Intensity of spatial connections between Serbia-Bosnia and Herzegovina IPA CBC project applications as arranged in terms of the type of cooperation Source: elaborated by the authors on the basis of EU data.

The irregular CBC type (4) is the subject of an upward trend compared with the single projects of the Hungarian-Serbian and Croatian-Serbian programme areas in the previous programming period (settlements outside the examined programme area are Budapest/HU, Hatvan/HU; Zagreb/ $\mathrm{CRO}$ ). This is the type predominating in the Serbian-Bosnian relationship, in line with the considerable size of the Bosnian programme area. It would be worth redefining the size of eligible areas under this Programme where the next programming period is concerned, in order to ensure a more visible cross-border impact.

Cross-border institutional relations are dominated by municipal relations: at levels that are local (local governments, governments of municipalities and cities), county (county governments) and provincial (in the case of Vojvodina), as well as between universities (high schools), NGOs, cultural and sporting associations, cultural institutions (museums or libraries), foundations and, regional institutions (regional development institutions, water directorates, chambers).

The completed project information available for the 2014-2020 Programming Period reveals that, where institutional relations are concerned, $54.6 \%$ of projects are between partners that are competent institutions. The corresponding values are $54.9 \%$ for the HU-SER Programme, $62 \%$ in the case of RO-SER, and $46 \%$ for CRO-SER. The relevant local governments are the entities most likely to implement competent or compatible partnerships (relations between local governments 
and municipal or county government, and cooperation between county and regional governments). On the other hand, it is most typical for regional institutions from Vojvodina to communicate with the second level of local government in Hungary, Croatia and Romania, i.e. with the county-level administrations. Competent relations between regional institutions (regional water directorates, chambers, regional development agencies, etc.) only appear to a more limited extent, although their low number may also be influenced by their profession-specific nature. University co-operations have become more restrained, as Hungarian and Serbian universities can only apply with 3 projects per independent legal entity, a significant restriction on both sides. In Serbia, it is only possible to submit 3-3 projects per faculty, in Hungary per university, which denotes an asymmetrical restriction. In Serbia, faculties are independent legal entities that can apply under their own jurisdiction, while in Hungary, universities are legal entities that include several faculties, so the latter cannot apply independently but only on behalf of their university. Participation is limited greatly in consequence. In some cases, therefore non-competent institutional relations are put in place, whereby - for example - Serbian university faculties apply to local governments, etc.

Though part-following of the methodology regarding the network connection of Polish-Ukrainian-Belarusian CBC projects (Dołzbłasz, 2018), we may assert that regional centres, regional and local government bodies, regional institutions, universities, regional development agencies and some local governments have put in place and developed a significant network of project connections under the current survey framework.

The Table 4 attests to the way in which only state, provincial and local government bodies are able to implement projects with a good network of connections and several winning applications, with the result that a significant impact on regional development is actually exerted.The background to this can be found at several key moments. Primarily, the application programmes are arranged in such a way that there are many areas (water management, infrastructure, health, and in part also economic development) in which only public bodies can apply, since they have the appropriate competences and legal powers to intervene in the given area. The system of connection networks is also related to this, as we have examined already, and it can be seen that there is good cooperation between the public institutions of the two countries, even as there are many cases in which neither party is willing to cooperate with other (civil or private) institutions as they lack appropriate competences and tools. The financing methodology is also related to this. As all programmes are post-financed, it is only institutions with a strong budgetary background that can provide the necessary pre-financing, often to the tune of millions of euros. The large number of universities is the result of their having the right expertise. In terms of both professional and management capacities, universities have the human resources to readily implement projects that are funded under programmes.

There is thus a basis for concluding that, unlike under previous calls, institutional relations now go beyond competency-based templates, which on the one hand may indicate the diversification of the relationship, but this may include the participation of one partner only as a tool. This assumption could be clarified on the basis of in-depth interviews and a thorough examination of the structure of the allocated grants.

If we compare the examined programmes with those in the 2007-2013 period, we can show clearly the shift from support for rural to support for urban projects, and from soft projects focused on training to infrastructure projects offering lasting results. The main reasons for this state of affairs lie in budget growth and a change in absorption capacity, primarily in terms of the human resources needed to implement projects. If we examine the complexity of the cross-border programmes implemented in the territory of Vojvodina in the last three EU budgeting periods, it 
can be concluded that the whole region is now moving along an organic development path in this respect, with programming principles now laid down properly. In the first programme, the focus was on training and institution-building; but larger-scale projects then came along, with the recent period even bringing strategically important developments.

Table 4. Institutions with most $\mathrm{CBC}$ project connections

\begin{tabular}{|c|c|c|c|c|}
\hline Institution & HU-SER & CRO-SER & RO-SER & SER-BiH \\
\hline $\begin{array}{l}\text { Autonomous Province of Voivodina Provincial Secretariats for } \\
\text { Regional Development, Interregional Cooperation Culture, } \\
\text { Public Information and Relations with Religious Communities ... } \\
\text { Education, Regulations, Administration and National Minorities } \\
\text { - National Communities } \\
\text { Urban Planning and Environmental Protection } \\
\text { Agriculture, Water Management and Forestry } \\
\text { Sports and Youth }\end{array}$ & 6 & 4 & 1 & \\
\hline $\begin{array}{l}\text { University of Novi Sad (Faculties) } \\
\text { Faculty of Technical Sciences } \\
\text { Faculty of Agriculture } \\
\text { Faculty of Science } \\
\text { Faculty of Medical Sciences }\end{array}$ & 13 & 6 & & \\
\hline European Affairs - Fund of Autonomous Province of Vojvodina & 5 & & & \\
\hline Vode Voivodine & 2 & 2 & 1 & \\
\hline City of Novi Sad & 1 & 2 & & \\
\hline City of Subotica & 2 & 1 & & \\
\hline City of Sombor & 1 & 2 & & \\
\hline
\end{tabular}

Source: elaborated by the authors on the basis of HUROSCG (2009), INTCROSER (2014), IPSERBIH (2014), INTROSER (2018) and INTHUSER (2020).

Due to the richness of their functional and institutional diversity, regional centres and larger cities build a more diverse spectrum of cooperation with several settlements due to the diversity of settlement relations. This can be perceived very clearly in the case of Timisoara in Romania or Novi Sad and Subotica. Although the latter has many connections with the Hungarian city of Szeged, it also has partnerships with several settlements in Croatia. The diversity characterising the Kiskunhalas relationship is an aspect of the Hungarian-Serbian programme that is worth highlighting (cf. Fig. 1-3).

Finally, as regards the obstacles to any reduction of the barrier effect outlined in the aforementioned paper by Medeiros (2018), we should point out that the case of Vojvodina does not include language barriers as much of a problem in $\mathrm{CBC}$, as inhabitants in all four border regions speak the same language as is spoken across the border. Instead, it is deficiencies in public-authority involvement, administrative asymmetry and $\mathrm{CBC}$ structures are characteristic.

The lack of public authority involvement can also be traced to this. It can be observed that the Hungarian, Romanian, Croatian and even Bosnian local-government systems are single-levelled, which means that all but the smallest settlements have their own local governments. In Serbia this is not the case, however. As a result, there are many cases in which municipalities make connections only with partner cities of similar size, while small settlements vainly seek individual good relations with the people of some settlements on the other side of the border, as there is no administrative body with which to connect and implement projects. 
In the HU-SER relationship, these characteristics have changed to the extent that currently 'Hungarian-Hungarian' relations and regional and state relations make a significant contribution to resolving barrier effects, even as these can only be filled with content thanks to the 2021-2027 Programming Period, in case the shortcomings that have arisen during the previous co-operations are to be incorporated during the programming.

Administrative asymmetries are caused by differences in the administrative systems on either side of a border. In Serbia, smaller settlements do not have their own local governments, but are condensed into municipalities. In each case this means a central (larger) settlement, along with (in some cases) up to 20 small settlements in its vicinity (e.g. Subotica). Under administrative law, these settlements also have an elected local government, but this lacks both authority and appropriate means, ensuring a role in name only. These municipal systems present a significant administrative disadvantage for those living in small settlements, as their participation in projects is also limited in this way.

Regarding the shortcomings of the CBC structure, the Danube-Cris-Muers-Tisza Euroregion could be mentioned as a potential CBC liaison institution. However, this is only a Euroregion that operates in the form of an association and has not been transformed into, for example, an European Groupings of Territorial Cooperation (EGTC). This reflects the lack of a CBC structure and is rooted in the way in which Serbian legislation still fails to recognise, for example, the concept of the EGTC - with the result that the country cannot be a member of any organisation with an official $\mathrm{CBC}$ structure.

\section{Conclusion}

The CBC projects completed so far in the 2014-2020 Programming Period in line with support received from the EU via Interreg-IPA II funds in part constitute a continuation of previous specific features. Although the spatial dimensions are predestined by the demarcated border regions, and while project calls are practically the same as their predecessors, some new features are also to be found. In addition to the very minimal majority of local governments in the recent implementations of the current planning period, regional centres and regional institutions dominate, while people-to-people projects remain negligible, whether in terms of value or number.

The regional-development impact expected as projects have been implemented proves to be minimal, and only in fact traceable in connection with infrastructural developments. The effects of the projects seeking economic development (which account for almost half of the total) have not yet emerged as significant or tangible, regionally speaking.

That said, there is no denying that EU funds have been able to resolve a number of problems that have existed for decades, and that stemmed from a peripheral situation. These developments would primarily have been tasks for the state, paid for by public institutions from the taxes of EU citizens, using project funding in areas beyond the EU's external borders. It is not scientifically proven, but the information gathered in the field outlines the above-mentioned process, which starts as early as at the programming stage, and goes through the selection of projects to subcontracting, with the aim being the financing by the EU of certain public tasks that have been neglected for decades.

Financially speaking, it is in many cases overpriced projects that have been supported, and in addition to their financial sustainability, the survival of the projects, and the expansion and further development of partnerships with new content have few innovative elements, especially in the 
context of the Romania-Serbia Programme. Due to the technical background vis-à-vis programme implementation, project managers need to place great emphasis on project administration and visibility elements, while in many cases adequate resources fail to persist in a way that might allow the results of project implementation to be maintained. Indeed, it may be that the Managing Authority does not even require or even seek this, as the level of indicators is important, while sustainability is not always checked up on more closely.

In the light of the analyses performed, it would seem that the development of public institutions is greater than that of small settlements, with the primary reason for this being a reflection of the technical implementation of projects: the implementation of a project, regardless of whether it is $85-100 \%$ supported (depending on the country and the institutional form of the applicant), gained post-financing in all cases, except that of Hungary. In the case of projects worth hundreds of thousands of euros, pre-financing is not always possible, except for public institutions.

This is also evidenced by the fact that large-scale and strategic projects are implemented solely by applicants based in regional centres and in possession of a significant institutional system and capital. Small settlements and NGOs on the periphery can only implement the projects with the smallest budgets, in many cases only by becoming indebted during the project-implementation phase, only going on to repay their debts when a project is completed.

In summary, as they are set against the programmes of the previous budgeting periods, the resources allocated in the first rounds of the 2014-2020 period did not bring about any positive changes in Vojvodina, either in terms of territorial development of the periphery or increasing people-to-people contacts in the immediate border region. In fact, the large number of projects entailing economic and infrastructural development must also have an impact on regional development in the long run, but this can only be demonstrated after all projects have been implemented, and their medium-term results examined.

This work provides only a brief overview of the first period under the examined Programme. We have yet to examine the second half of the period, whose projects are now under implementation. Considerable resources have been allocated to both the Hungarian and Romanian programs, which may overshadow the results outlined above. Only a full and in-depth examination of all the programs may give a comprehensive picture of the results achieved, which should be based on an analysis of in-depth interviews with the implementers and, of course, an examination of the achievement of the indicators required by the programs.

The planning of the 2021-2027 Programming Period on the examined border sections has been going on for almost two years. Just as it has affected everything else, so the situation with the COVID-19 pandemic has had an effect here, in slowing down the planning process. On the plus side, the slowdown may hopefully offer an additional opportunity for public and professional structures to assess the gaps existing within the cross-border areas the Interreg-IPA CBC Programmes have set out to develop.

In the context of the new programming period, it would be necessary to allow for trilateral $\mathrm{CBC}$ applications in respect of environmental-nature protection-water management issues on both triple border of Vojvodina, as a NUTS 2 region (involving the Serbia-Hungary-Croatia and SerbiaRomania-Bulgaria triple borders along the Danube).

Our views and studies sustain the idea that, in addition to cooperation over the environment, nature protection and water management, the most important thing is to increase the mobility of people, as a significant step forward in terms of relations and labour flow, but also the development of tourism. This mobility requires open, interoperable borders, and thus also adequate infrastructure. Labour mobility is preconditioned by economic development, which allows for the creation of new 
jobs. In addition to these basic conditions, there is a need for tourism infrastructure and the flow of information to be enhanced, even as natural and built heritage is maintained. The comprehensive set of all listed priorities presupposes the opportunities for regional development of Vojvodina in the 2021-2027 Programming Period.

\section{Acknowledgement}

The research has been implemented with support provided from the National Research, Development and Innovation Fund of Hungary (NKFI K 134903 Geopolitical Processes and Imaginaries in Central Europe: States, Borders, Integration and Regional Development).

\section{References}

Bastian, J. (2011, March 11). Cross-border cooperation in the Western Balkans: roadblocks and prospects. TransConflict. Retrieved from http://www.transconflict.com/2011/03/cbc-wb-roadblocksprospects-163/

Demidov, A., \& Svensson, S. (2011). Friendly Neighbours: Increasing the Potential of European Neighbourhood Policy Cross-Border Cooperation Initiatives. Policy Brief, 4. Retrieved from http://cps.ceu. edu/sites/cps.ceu.edu/files/cps-policy-briefpasos-cross-border-cooperation-2011.pdf

Dołzbłasz, S. (2018). A network approach to transborder cooperation studies as exemplified by Poland's eastern border. Geographia Polonica, 91(1), 63-76. https://doi.org/10.7163/GPol.0091

EC (2014). Regulation (EU) No 232/2014 of the European Parliament and of The Council of 11 March 2014 establishing a European Neighbourhood Instrument. OJ EU L 77/27.

HUROSCG (2009). Hungary/Romania and Hungary/Serbia\&Montenegro, 2004-2006 Final programme evaluation. VÁTI Hungarian Public Nonproit Company for Regional Development and Town Planning, Hungarian Academy of Sciences Centre for Regional Studies, West Hungarian Research Institute.

INTCROSER (2014). Interreg-IPA CBC Croatia-Serbia Programme 2014-2020. Retrieved from http:// Www.interreg-croatia-serbia2014-2020.eu/

INTHUSER (2020). Interreg-IPA CBC Hungary-Serbia Programme 2014-2020. Retrieved from http:// www.interreg-ipa-husrb.com/en/file/5823/

INTROSER (2018). INTERREG-IPA CBC Romania-Serbia Programme 2014-2020. Retrieved from http:// www.romania-serbia.net/?page_id $=163$

IPSERBIH (2014). IPA CBC Programme 2014-2020 Serbia-Bosnia and Herzegovina. Retrieved from https://srb-bih.org/en/dokumenti/programski-dokumenti/

Knippschild, R. (2005). Cross-Border Cooperation as a New Tool for Urban Development in Border Regions? Europa XXI, 13, 123-128.

Kolosov, V. A., Klemeshev, A. P., Zotova, M. V., \& Sebentsov, A. B. (2015). Russia-European Union Borderlands: Transboundary Gradients, Interactions and Current Challenges. International Journal of Economics and Financial Issues, 5, 5-12.

Medeiros, E. (2015). Territorial Impact Assessment and Cross-Border Cooperation. Regional Studies, Regional Science, 2(1), 97-11. https://doi.org/10.1080/21681376.2014.999108

Medeiros, E. (2018). Should EU cross border cooperation programmes focus mainly on reducing border obstacles? Documents d'Anàlisi Geogràfica. https://doi.org/10.5565/rev/dag.517

Nagy, I. (2020). Cross-border cooperation on the external borders of the $\mathrm{EU}$ and the impact of the received EU CBC funds on AP Vojvodina/Serbia. Belgeo, 2. https://doi.org/10.4000/belgeo.38732

Nagy, I., Ricz, A., Ribár, Gy., \& Nagy, M. (2015). Spremnost i pripremljenost lokalnih samouprava AP Vojvodine za prijem i korišćenje razvojnih fondova Evropske unije [Readiness and preparedness of local self-governments in AP Vojvodina for receiving and using development funds of the European Union]. Temerin: Szerbia Prospero-Temerinske novine. 
Ocokoljic, S. (2013). Towards EGTC: Evaluating Influence of the Perception of the Borders on the Cross-Border Policies and Cooperation in Serbia. Discussion Papers, 91.

Perkmann, M. (2003). Cross-Border Regions in Europe: Significance and Drivers of Regional Cross-Border Co-operation. European Urban and Regional Studies, 10(2),153-171. https://doi.org/10.1177/0969 776403010002004

Popescu, G. (2008). The conflicting logics of cross-border reterritorialization: Geopolitics of Euroregions in Eastern Europe. Political Geography, 27(4), 418-438. https://doi.org/10.1016/j.polgeo.2008.03.002

Ricz, A. (2013). A határon átívelő projektek újabb hatásai Vajdaság területi fejlődésére. Régiók Fejlesztése, 2.

Ricz, A. (2018). A határon átívelő programok hatásai a Vajdaság területi fejlődésére [The effects of cross-border cooperation programs on Vojvodina's regional development]. Tér és Társadalom, 32(1), 161-179. https://doi.org/10.17649/TET.32.1.2877

Scott, J.W. (2015). Bordering, Border Politics and Cross-Border Cooperation in Europe. In F., Celata \& R., Coletti (Eds.). Neighbourhood Policy and the Construction of the European External Borders (pp. 27-44). Basingstoke: Springer.

Tamminen, T. (2012). Re-Establishing Cross-Border Cooperation Between Montenegro, Kosovo and Albania: The Balkans Peace Park and Local Ownership. In J., Lindstedt \& M., Wahlström (Eds.). Balkan Encounters - Old and New Identities in South-Eastern Europe (pp. 125-151). Helsinki: Slavica Helsingiensia. 